\title{
Hvid kryptonit fundet i Serbien - bliver "Superman Returns" den sidste film?
}

Af GeologiskNyts webmaster, Steen Laursen

Geologerne i Jadar Dalen i Serbien fik sig noget af en overraskelse, da engelske mineraloger udtalte deres dom over det mineral, som netop var kommet op af Balkans undergrund. Det var intet mindre end det Supermandsomstyrtende mineral kryptonit.

Supermands helteunivers er kollideret med den virkelige verden i Jadar Dalen i Serbien, hvor heltens akilleshæl er boret op af undergrunden. Det er mineralet kryptonit, som er kommet for dagen. I den sidste film har det fået den kemiske betegnelse "sodium lithium boron silicate hydroxid" - en betegnelse, som intet kendt mineral har.

\section{Kun Google vidste besked}

Eller rettere havde. For sidste efterår undrede de lokale geologer i Serbien sig over et underligt hvidligt og pulveragtigt mineral, som udgjorde ret store dele af deres boreprøver. Derfor sendte de noget af mineralet til Natural History Museum i London. Her undersøgte forskerne mineralet og bestemte dets kemiske sammensætning, og med den i hånden pløjede de faglitteraturen igennem. Det kunne jo være, at andre var stødt på mineralet før. Det gav intet resultat.

Men det gjorde Google til gengæld. Da Chris Stanley fra Natural History Museum i London havde opgivet faglitteraturen, prøvede han internettet, og dér var der bid med det samme. Men det var en noget uventet fisk, der bed på krogen. For i den seneste Supermandsfilm, "Superman Returns", stjæler ærkeslynglen Lex Luther kryptonit fra et museum. Mineralet ligger i en kasse, men

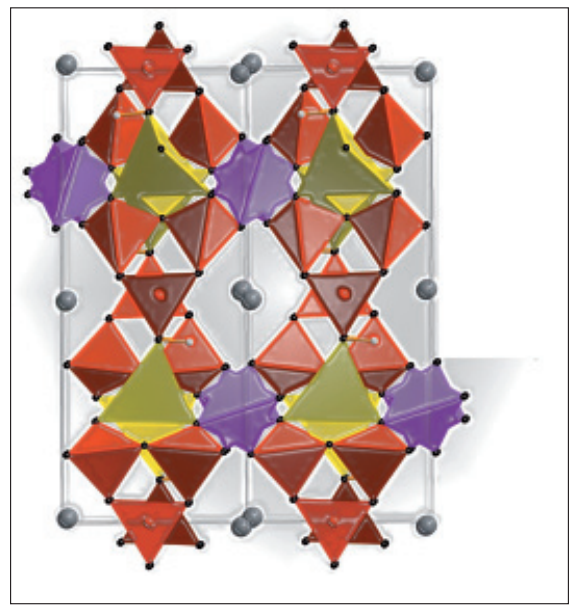

Strukturen har et todimensionelt hjørnedelende tetrahedralt netvoerk af litium, silicium og bor. En scerlig egenskab ved strukturen er natriumkanaler, som er nogenlunde parallelle med c-aksen, medens borosilikatlagene ligger $i$ (001) planet. Brintatomet er bundet til et af iltatomerne $i$ den trekantede $\mathrm{BO}_{3}$-enhed og danner en hydrogenbinding til et af iltatomerne $i$ det tetrahedrale netvork. Strukturen er tilsyneladende unik, idet den ikke har nogle direkte strukturelle analoger. (Gafik: Forfatteren)

der står ikke "kryptonit" på kassen, der står "sodium lithium boron silicate hydroxid".

\section{Hvid kryptonit}

"Det nye mineral indeholder ikke fluor, og det er mere hvidt end grønt", erkender Chris Stanley, som nu har kigget nærmere på Supermands tegneseriekryptonit. "Men i alle andre henseender passer kemien til kryptonit. Vi bliver nødt til at være forsigtige med det, for vi vil jo ikke berøve Jorden dens mest berømte superhelt".
Serbiens kryptoinit er godt nok hvidt og ikke grønt, men til gengæld bliver det et sted mellem pink og orange, når man lyset på det med ultraviolet lys. Så da tegneseriekryptonitten findes i adskillige farver, er pink slet ikke noget dårligt udgangspunkt.

\section{Sådan cirka ufarligt}

Det virkelige mineral har den egenskab tilfælles med tegneseriemineralet, at det er aldeles uskadeligt for mennesker. Det kunne man jo godt tage som indtægt for, at det til gengæld er meget skadeligt for Supermand. Men da Supermand ikke har stillet op til nogen test, og da der ikke er lavet rotteforsøg, er der endnu ingen, som kan sige, om "Superman Returns" bliver den sidste supermandfilm.

Men kryptonitten kommer nu ikke til at hedde kryptonit. For at et mineral kan kaldes kryptonit, skal det indeholde en masse krypton. Men det er jo en ædelgas, som ikke sådan lader sig binde. Alternativt kan mineralet komme fra et sted, der hedder Krypton, men det gør det ikke. Det kommer fra Jadar Dalen, og derfor kommer det til at hedde Jadarite.

\section{Sjældne mineraler er almindelige}

Hvert år finder forskerne 30-40 nye mineraler, men kryptonitten falder uden for de almindelige mineraler, for normalt er der tale om nogle få og små krystaller, som kun lige kan ses med mikroskop. Kryptonittens krystaller er ganske vist også bitte små, men til gengæld udgør de hele lag. Så lokalt findes det altså i ret store mængder.

Lad os bare slutte med det helt essentielle i mineralet. Kryptonit er monoklint med parametrene $\mathrm{a}, \mathrm{b}$ og $\mathrm{c}$ på henholdsvis $6,7651,13,8063$ og 7,6912, og beta er 124,099 grader. Den kemiske formel er $\mathrm{LiNaSiB}_{3} \mathrm{O}_{7}(\mathrm{OH})$. 